\title{
Mammographic density in asymptomatic menopausal women: correlation with clinical and sonographic findings*
}

\author{
Densidade mamográfica em mulheres menopausadas assintomáticas: correlação com dados clínicos \\ e exames ultrassonográficos \\ Beatriz Regina Alvares ${ }^{1}$, Christian Henrique de Andrade Freitas ${ }^{2}$, Rodrigo Menezes Jales ${ }^{3}$,
Orlando José de Almeida ${ }^{4}$, Emílio Francisco Marussi ${ }^{5}$
}

Abstract Objective: To evaluate mammographic breast density in asymptomatic menopausal women in correlation with clinical and sonographic findings. Materials and Methods: Mammograms and clinical and sonographic findings of 238 asymptomatic patients were retrospectively reviewed in the period from February/2022 to June/2006. The following variables were analyzed: mammographic density patterns, sonographic findings, patients' age, parity, body mass index and use of hormone replacement therapy. Results: Age, parity and body mass index showed a negative correlation with breast density pattern, while use of hormone replacement therapy showed a positive correlation. Supplementary breast ultrasonography was performed in 103 (43.2\%) patients. Alterations which could not be visualized at mammography were found in 34 (33\%) of them, most frequently in women with breast density patterns 3 and 4 . Conclusion: The authors concluded that breast density patterns were influenced by age, parity, body mass index and time of hormone replacement therapy. Despite not having found any malignant abnormality in the studied cases, the authors have observed a predominance of benign sonographic abnormalities in women with high breast density patterns and without mammographic abnormalities, proving the relevance of supplementary ultrasonography to identify breast lesions in such patients.

Keywords: Mammogram; Breast density; Menopausal; Ultrasonography.

Resumo Objetivo: Avaliar a densidade mamográfica de mulheres menopausadas, assintomáticas, correlacionando com dados clínicos e ultrassonográficos. Materiais e Métodos: Foram analisados, retrospectivamente, as mamografias e os dados clínicos e ultrassonográficos de 238 pacientes assintomáticas, no período entre fevereiro de 2002 e junho de 2006. As variáveis analisadas foram: padrões de densidade mamográfica, achados ultrassonográficos, idade, paridade, índice de massa corporal e uso de terapia de reposição hormonal. Resultados: Idade, paridade e índice de massa corporal apresentaram relação inversa com os padrões de densidade mamográfica, enquanto o uso de terapia de reposição hormonal apresentou relação direta. Foram realizados exames ultrassonográficos complementares em 103 (43,2\%) pacientes, sendo constatadas alterações em 34 (33\%) delas. Os nódulos ultrassonográficos foram mais frequentes nas mulheres com padrões mamários 3 e 4 e sem expressão mamográfica. Conclusão: Concluímos que os padrões mamográficos de densidade foram influenciados pela idade, índice de massa corporal, paridade e tempo de uso de terapia de reposição hormonal. Apesar de não termos encontrado alterações malignas nos casos estudados, evidenciamos alterações ultrassonográficas benignas nas mulheres com padrões mamários de alta densidade e que apresentaram mamografias sem alterações, demonstrando a importância da ultrassonografia complementar para a detecção de lesões mamárias nessas pacientes.

Unitermos: Mamografia; Densidade mamária; Menopausadas; Ultrassonografia.

Alvares BR, Freitas CHA, Jales RM, Almeida OJ, Marussi EF. Mammographic density in asymptomatic menopausal women: correlation with clinical and sonographic findings. Radiol Bras. 2012 Mai/Jun;45(3):149-154.

\footnotetext{
* Study developed at Hospital da Mulher Prof. Dr. José Aristodemo Pinotti - Centro de Atenção Integral à Saúde da Mulher (CAISM), Faculdade de Ciências Médicas da Universidade Estadual de Campinas (FCM-Unicamp), Campinas, SP, Brazil.

1. PhD, Professor at Department of Radiology, Faculdade de Ciências Médicas da Universidade Estadual de Campinas (FCMUnicamp), Campinas, SP, Brazil.

2. Graduate Student of Medicine, Faculdade de Ciências Médicas da Universidade Estadual de Campinas (FCM-Unicamp), Campinas, SP, Brazil.

3. Master, MD, Physician Assistant at the Unit of Echography, Centro de Atenção Integral à Saúde da Mulher (CAISM), Faculdade de Ciências Médicas da Universidade Estadual de Campinas (FCM-Unicamp), Campinas, SP, Brazil.
}

4. PhD, MD, Physician Assistant at the Unit of Radiology, Centro de Atenção Integral à Saúde da Mulher (CAISM), Faculdade de Ciências Médicas da Universidade Estadual de Campinas (FCM-Unicamp), Campinas, SP, Brazil.

5. PhD, Professor at Department of Gynecology and Obstetrics, Faculdade de Ciências Médicas da Universidade Estadual de Campinas (FCM-Unicamp), Campinas, SP, Brazil.

Mailing Address: Christian Henrique de Andrade Freitas. Rua H 23 A, n 114, Campus do CTA. São José dos Campos, SP, Brazil, 12228-480. E-mail: christiansantista@hotmail.com

Received September 15, 2011. Accepted after revision May 10, 2012.

\section{INTRODUCTION}

Screening mammography is aimed at the early detection of breast cancer in asymptomatic women and it is a routine examination for women aged over $50^{(\mathbf{1})}$. The interpretation of mammographic images may become more difficult because of the breast tissue density pattern, and hence the higher rate of false negative results ob- 
served in dense breasts. In such cases, supplementary ultrasonography (US) ${ }^{(2)}$ may be indicated.

As the estrogen and progesterone levels decreases in the female body, an increase in the amount of fat tissue may be observed in relation to the fibroglandular tissue of the breast. The greater the adipose tissue ratio in the breast, the lower is the breast density found at mammography. Some factors may be associated with breast density, such as age, body mass index (BMI), parity and time on hormone replacement therapy $(\mathrm{HRT})^{(\mathbf{3 , 4})}$. Some authors have demonstrated that age may influence the breast density pattern in women ${ }^{(5,6)}$. Other authors have reported that nulliparity may be correlated with increased breast density, particularly in women aged under 55 , while parity 2 and over has a contrary effect $^{(6,7)}$. Additionally, BMI may present an inverse relationship with the breast density pattern ${ }^{(6)}$. Studies have demonstrated HRT may responsible for increased breast density, because of changes resulting from the increase in estrogen and progesterone serum concentrations ${ }^{(\mathbf{8 , 9})}$.

The present study was aimed at evaluating the mammographic breast density in asymptomatic menopausal women, and establishing correlation with clinical and sonographic findings.

\section{MATERIALS AND METHODS}

The present descriptive and retrospective study was developed in the Centro de Atenção Integral à Saúde da Mulher (CAISM), at the Faculdade de Ciências Médicas da Universidade Estadual de Campinas (FCM-Unicamp), Campinas, SP, Brazil, comprising the review of mammograms of 238 asymptomatic women assessed in the Menopause Clinic of the author's institution in the period from February 2022 to June 2006. Clinical records and sonographic data (as indicated) were also reviewed.

The analyzed variables were the following:

- Breast density patterns (according to the Breast Imaging Reporting and Data System - BI-RADS ${ }^{\circledR}$ classification): 1 - breasts with a predominance of adipose tissue (fibroglandular tissue <
25\%); 2 - breasts with sparse fibroglandular densities (fibroglandular tissue percentage between $25 \%$ and $50 \%$ ); 3 - heterogeneously dense breasts (fibroglandular tissue percentage between $51 \%$ and $75 \%$ ); 4 - dense breasts (fibroglandular tissue percentage $>75 \%)^{(\mathbf{1 0 - 1 2})}$.

- BMI: the index corresponding to the squared weight/height ratio, the weight being considered as normal with BMI between 19 and $25 \mathrm{~kg} / \mathrm{m}^{2}$; overweight, between 25 and $30 \mathrm{~kg} / \mathrm{m}^{2}$, and obesity, $>30 \mathrm{~kg} / \mathrm{m}^{2}$.

- Age: the patients were classified according to the following age groups: < 40 years, 41-50 years, 51-65 years and $\geq 66$ years.

- Parity (number of live births): women with parity 2 and over were considered as being multiparous.

- HRT: only women under combined HRT, with daily oral intake, for a maximum period of five years, were included.

- Sonographic findings: the US images were described as per the BI-RADS-US.

The present study included women with no known breast disorder who underwent mammographic screening in the Menopause Clinic of CAISM. A Mammomat 3000 Nova equipment (Siemens AG, Medical Solutions; Erlangen, Germany) was utilized for acquisition of craniocaudal and mediolateral oblique images. Exclusion criteria were the following: previous breast cancer surgery and mammographic abnormalities

The mammographic images were independently reviewed by two experienced specialized radiologists. Mammographic findings and breasts density were classified according to the BI-RADS. The divergent findings were reviewed one more time, with a view on reaching an interobserver consensus.

The collected data were analyzed with the software Epi. Info 6 and Excel 2010 worksheets. The mammographic density patterns 1 and 2, as well as the patterns 3 and 4, were grouped for analysis as described on the results table. The chi-square $\left(\chi^{2}\right)$ and logistic regression tests were performed, with a confidence interval of $95 \%$ and $p<0.05$ as significance level.
The project was approved by the Committee for Ethics in Research of FCMUnicamp under protocol No. FR238725, CAAE 0023.0.146.000-09.

\section{RESULTS}

The data found according to the analyzed variables are organized on Table 1 as follows: patient distribution according to breast density pattern; $\chi^{2}$ test; contingency coefficient and correlation coefficient utilized for logistic regression; and $p$-value. Amongst the 238 patients, the ages ranged from 36 to 78 years, with a mean age of 56.8 years and standard deviation of 10.8 years. The distribution by age group was the following: a) up to 40 years, 43 patients (18\%); b) 41 to 50 years, 72 patients $(30.2 \%)$; c) 51 to 65 years, 66 patients $(27.7 \%)$; d) 66 years and over, 57 patients (23.9\%). As regards mammographic density according to the BI-RADS classification, 158 patients $(66.4 \%)$ presented patterns 1 and 2 (fatty and predominantly fatty breasts) and $80(33.6 \%)$ presented patterns 3 and 4 (heterogeneously dense and dense breasts).

Inverse relationship was observed in the correlation between the variables age and breast density pattern, with $p<0.05$ ( $p=$ 3.44E-6). Upon BMI evaluation, $20 \%$ of the patients presented BMI $<20 ; 36 \%$ presented BMI between 20 and 25, 28\% presented overweight, while $16 \%$ were obese. Inverse relationship was observed between breast density and BMI, with $p<0.05$ ( $p=$ 6.43E-12).

Parity presented inverse association with breast density pattern, with $p<0.05$ $(p=2.12 \mathrm{E}-9)$. The inverse relationship can be confirmed by logistic regression, since there was a predominance of fatty breasts in women with parity 2 and over as compared with uniparous and nulliparous women.

Direct relationship was observed between HRT and mammographic density pattern, with increased breast density with the longer utilization of HRT, with $p<0.05$ $(p=0.0180)$.

Supplementary US was performed in 103 women, $39(38 \%)$ of them with mammographic density patterns 1 and 2, and 64 $(62 \%)$ with mammographic density pat- 
Table 1 Distribution of patients according to mammographic density pattern and clinical variables.

\begin{tabular}{|c|c|c|c|c|c|c|c|}
\hline Variable & VP & MP 1 and 2 & MP 3 and 4 & $\chi^{2}$ test & CC & $r$ & $p$ \\
\hline \multirow{4}{*}{ BMI } & $<20$ & 16 & 31 & \multirow{4}{*}{55.132} & \multirow{4}{*}{0.43} & \multirow{4}{*}{-0.29} & \multirow{4}{*}{$6.43 \mathrm{E}-12$} \\
\hline & $20-25$ & 47 & 39 & & & & \\
\hline & $25-30$ & 59 & 8 & & & & \\
\hline & $>30$ & 36 & 2 & & & & \\
\hline \multirow{4}{*}{ Age } & $<40$ years & 32 & 36 & \multirow{4}{*}{29.167} & \multirow{4}{*}{0.33} & \multirow{4}{*}{-0.82} & \multirow{4}{*}{$3.44 \mathrm{E}-6$} \\
\hline & $41-50$ years & 43 & 19 & & & & \\
\hline & $51-65$ years & 31 & 20 & & & & \\
\hline & $\geq 66$ years & 52 & 5 & & & & \\
\hline \multirow{3}{*}{ Parity } & 0 & 14 & 33 & \multirow{3}{*}{39.940} & \multirow{3}{*}{0.37} & \multirow{3}{*}{-0.16} & \multirow{3}{*}{$2.12 \mathrm{E}-9$} \\
\hline & 1 child & 35 & 20 & & & & \\
\hline & $>1$ child & 109 & 27 & & & & \\
\hline \multirow{3}{*}{ HRT } & 0 & 58 & 21 & \multirow{3}{*}{8.032} & \multirow{3}{*}{0.18} & \multirow{3}{*}{0.26} & \multirow{3}{*}{0.018} \\
\hline & 1 year & 72 & 32 & & & & \\
\hline & $>1$ year & 28 & 27 & & & & \\
\hline
\end{tabular}

VP, variable parameters; MP, mammographic pattern; CC, contingency coefficient; $r$, correlation coefficient.

terns 3 and 4 . In the patient group with patterns 1 and 2, three women had simple cysts smaller than $1 \mathrm{~cm}$ in diameter, and one had simple cysts between $1 \mathrm{~cm}$ and 2 $\mathrm{cm}$. In the patient group with mammographic patterns 3 and 4, $16(25 \%)$ had simple cysts smaller than $0.5 \mathrm{~cm}, 11$ (17.2\%) had cysts between $0.5 \mathrm{~cm}$ and 1 $\mathrm{cm}$, one presented an image compatible with a circumscribed solid mass while one presented a complicated cyst (BI-RADS category 3). In one patient, a complex cyst (BI-RADS category 4) was found. Mammography did not demonstrate findings corresponding to the lesions detected at ultrasonography in the patients with density patterns 3 and 4 (Figures 1 and 2). The cases classified as BI-RADS 3 were followed-up according to the routine of the CAISM Mastology Service. The patient with complex cyst classified as BI-RADS 4 was submitted to US-guided percutane- ous biopsy of a fragment whose anatomopathological result demonstrated intraductal papilloma without atypias and with apocrine metaplasia (benign lesion). A supplementary excision biopsy of the lesion was performed according to the service protocol and confirmed the diagnosis.

The odds ratio calculation for the sonographic diagnosis was 7.72 , with $95 \%$ confidence interval (2.46-24.26), demonstrating that breasts with mammographic density patterns 3 or 4 present a higher probability of findings at US than breasts with 1 and 2 density patterns.

\section{DISCUSSION}

According to the Instituto Nacional de Câncer (National Cancer Institute), mammography is the method of choice for the breast cancer screening in women aged over $50^{(\mathbf{1})}$. However, patients with dense breasts may present false negative mammographic results, so supplementary US is indicated for being a low cost, easily accessible and well tolerated imaging method ${ }^{(2,13)}$. Moreover, the association between mammography and US presents a sensitivity > $90 \%$ in the detection of breast changes in breasts made up of less fat content ${ }^{(14-18)}$.
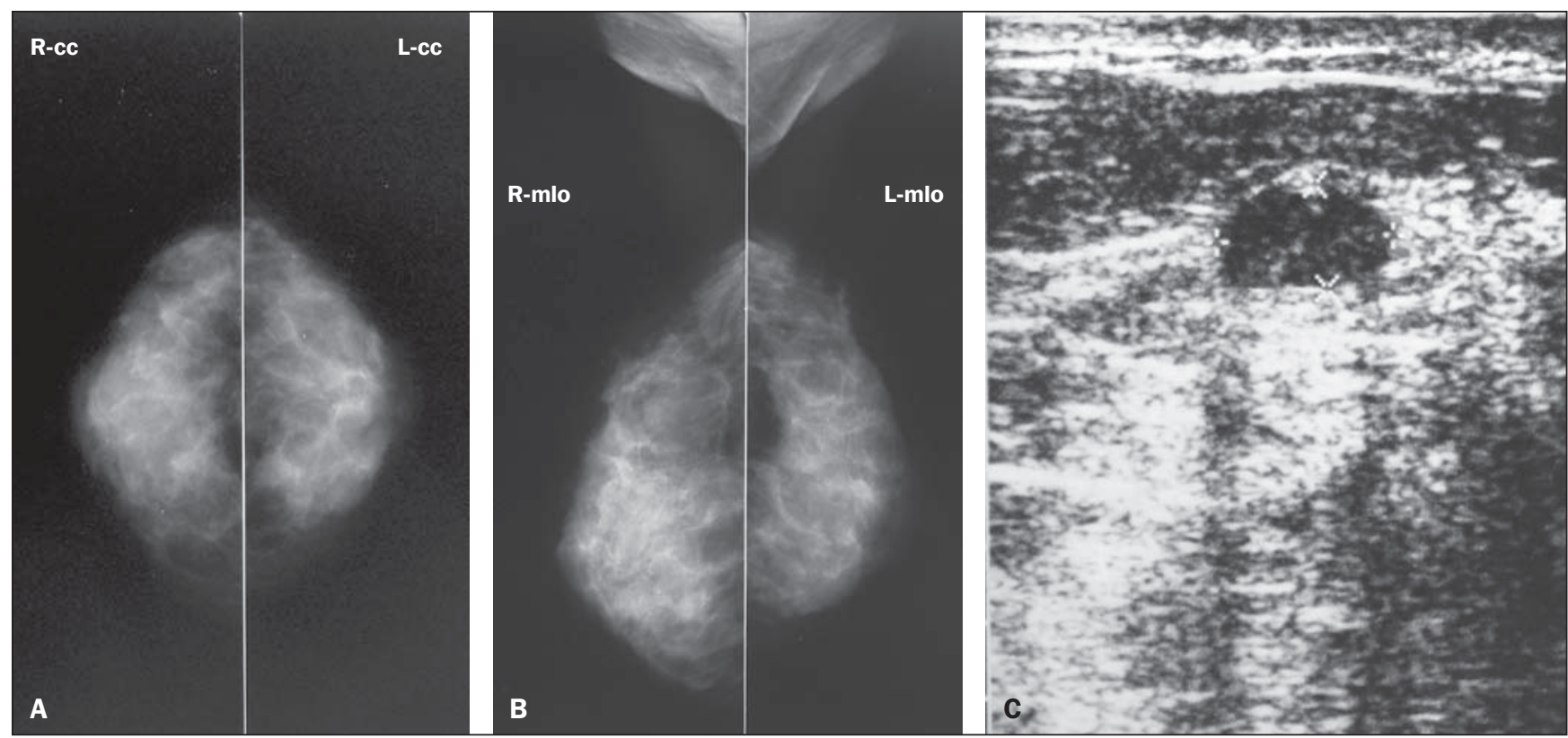

Figure 1. Asymptomatic, 56-year-old patient, menopausal for three years, under combined HRT for the past two years, BMI = 26.2, parity $=1$ child. A,B: Mammogram showing dense breasts (mammographic density pattern 4), according to the BI-RADS classification. C: Supplementary US demonstrating the presence of hypoechoic mass, with circumscribed contour, parallel orientation with posterior acoustic shadowing, located in the superomedial quadrant of the right breast, measuring $12 \times 10 \times 6 \mathrm{~mm}$, classified as BI-RADS 3 . 

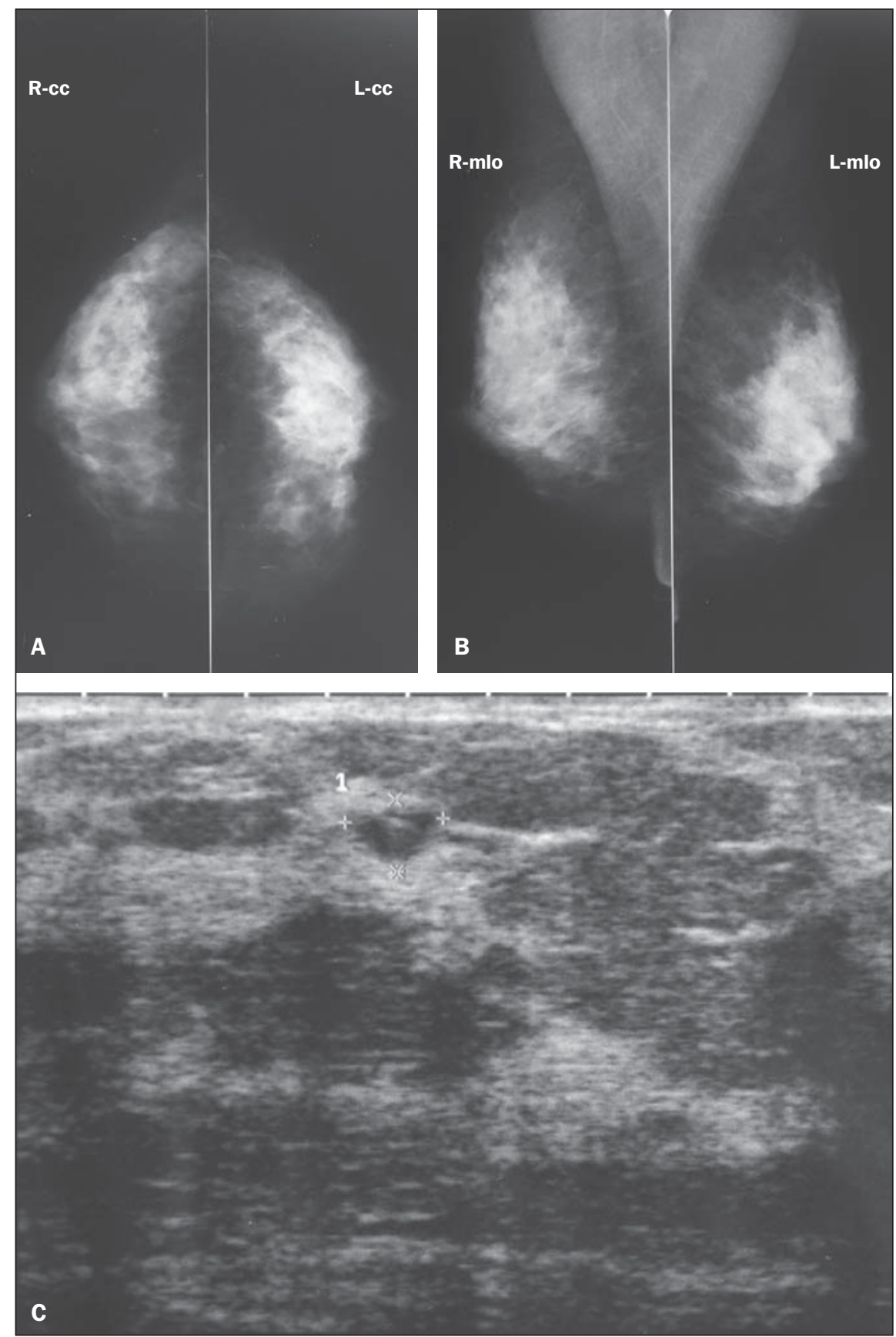

Figure 2. Asymptomatic, 53-year-old patient, menopausal for the last 4 years, under combined HRT for 3 years, $\mathrm{BMI}=23.8$, nulliparous. A,B: Mammogram shows density pattern 4 according to the BI-RADS classification. C: Supplementary US demonstrating anechoic, sparse round images measuring between 8 and $6 \mathrm{~mm}$ in diameter, besides oval image with $6 \times 4 \mathrm{~mm}$ (identified on the figure) with debris in the superolateral quadrant of the right breast (complicated cyst - BI-RADS 3).

The present study has found that asymptomatic women with dense breasts have a higher probability of findings at US than those with predominantly fatty breasts, confirming the findings reported by other authors $^{(\mathbf{1 4}-19)}$. According to Houssami et al., the performance of US in women aged = also report a positive association between such density pattern and a higher incidence of breast neoplasias, with a three- to sixfold increase in the risk for development of breast cancer ${ }^{(17-19)}$

In the present study sample comprising 238 cases, no case of breast cancer was detected. Studies with larger casuistries report that for every 1000 normal mammograms, 3 to 4 cases of cancer are detected at supplementary US ${ }^{(\mathbf{2 0 , 2 1 )}}$. At the American College of Radiology Imaging Network (ACRIN 6666), Berg et al. have evaluated the benefits from combined mammography/ultrasonography for breast cancer screening in high-risk patients with dense or heterogeneously dense breasts, and found an increased rate of detection of breast cancer in spite of the increase in the number of false positive results ${ }^{(22)}$. Most recently, Youk \& Kim reviewed the literature on the subject and confirmed the relevance of the early detection of breast cancer in women with dense breasts. However, in such a review, the argument that US presents a higher rate of false positive results than mammography also came up, additionally to its operator-dependence and limitations in the detection of microcalcifications $^{(23)}$

The present study has also assessed the relationship between breast density and BMI, age, parity and use of HRT. The presence of a high BMI results in greater amount of adipose tissue in the breast and greater number of adipocytes, the cells responsible for the peripheral conversion of cholesterol into estrogen, besides producing several other hormones, which favors the increase in breasts size and decrease of mammographic density ${ }^{(\mathbf{2 4}, 25)}$. Sung et al. have evaluated the relationship between BMI and breast constitution, and observed a increase in adipose tissue in the breasts with the increase of $\mathrm{BMI}^{(26)}$. Figueira et al. have evaluated 849 patients at different stages of their reproductive life and demonstrated that the breast density pattern is affected by certain factors such as the BMI and age, observing a significant inverse relationship $(p<0.05)$ between such factors and mammographic density ${ }^{(\mathbf{6})}$.

Aging brings physiological changes to the female body, influencing breast density because of menopause that causes involu- 
tion of the breast parenchyma ${ }^{(3,4)}$. In a study with pre- and postmenopausal women, Figueira et al. have found an inverse relationship between age and breast density pattern. As aging progresses, the female hormonal production slows down until its complete interruption at menopause which, among the Brazilian population, occurs on average at the 5th and 6th decades of life. A progressive fatty replacement of the breast parenchyma occurs even before menopause, and such a process is enhanced after menopause ${ }^{(\mathbf{6})}$. Kelemen et al. have demonstrated progressive decrease in the breast density with aging ${ }^{(27)}$. Siqueira et al. have developed a similar study; but such authors evaluated only post-menopausal women, and have not found statistically significant association between age and mammographic density pattern. The authors have explained such finding by the high prevalence of breasts with lower density in the group of women included in their study ${ }^{(24)}$.

Mezzacappa \& Mezzacapa Filho have reported that breasts undergo profound physiological changes during the gestational period; glandular differentiation is the main of such changes. The specialized glandular tissue presents a greater accumulation of adipose tissue than the non-specialized tissue, as fat is a raw material for the production of breast milk. Parity is responsible for the marked glandular differentiation for milk production ${ }^{(28)}$. ElBastawissi et al. have studied more than 25 thousand patients, demonstrating an inverse relationship between parity and breast density ${ }^{(\mathbf{2 9})}$.

Hormone replacement therapy has been utilized in menopause to control climacteric symptoms. Consequently, the utilization of exogenous hormones after ovarian failure leads to changes in the female body, breast changes for example. Hormone replacement therapy is responsible for the increase in breast density because of the changes resulting from elevation in the estrogen and progesterone serum concentrations ${ }^{(8,9)}$. Yaghjyan et al. have demonstrated a direct relationship between HRT and changes in breast density, with decrease in the mammographic sensitivity ${ }^{(30)}$. In the present study, the authors observed association between mammographic den- sity pattern and age, BMI, parity and HRT. An inverse association was observed between mammographic density pattern and age range, BMI and parity, besides the direct relationship with HRT duration. Thus, even after menopause, many women can present dense breasts, reducing the mammography sensitivity in the detection of benign, probably benign lesions and lesions with varied degrees of suspicion for malignancy. The utilization of US in this group of patients is very important for the early detection of such breast lesions, which are hidden by the high density of the fibroglandular tissue at mammography ${ }^{(31)}$.

Thus, a more comprehensive study approaching menopausal women is required, with a detailed analysis of each patient's clinical data associated with lower breast density, such as age, BMI and parity, or greater breast density with HRT duration $^{(28,31)}$, as the authors have found in the present study. Despite the absence of malignant findings, the authors have observed a predominance of sonographic alterations in the women with mammographic density patterns and normal mammograms, which demonstrates the relevance of supplementary US for the detection of breast lesions in such patients.

\section{REFERENCES}

1. Brasil. Ministério da Saúde. Instituto Nacional de Câncer. Controle do câncer de mama: documento de consenso. Rio de Janeiro, RJ: INCA, 2004. [acessado em 21 de fevereiro de 2010]. Disponível em: http://www1.inca.gov.br/publicacoes/ Consensointegra.pdf

2. Checka CM, Chun JE, Schnabel FR, et al. The relationship of mammographic density and age: implications for breast cancer screening. AJR Am J Roentgenol. 2012;198:292-5.

3. Shifren JL, Schiff I. Menopausa. In: Berek JS, editor. Berek \& Novak - Tratado de ginecologia. $14^{\mathrm{a}}$ ed. Rio de Janeiro, RJ: Guanabara Koogan; 2008. p. 974-84.

4. Bossemeyer R. Aspectos gerais do climatério. In: Fernandes CE, Melo NR, Wehba S, editores. Climatério feminino - fisiopatologia, diagnóstico e tratamento. $1^{a}$ ed. São Paulo, SP: Lemos; 1999. p. 17-33.

5. Pinsky RW, Helvie MA. Mammographic breast density: effect on imaging and breast cancer risk. J Natl Compr Canc Netw. 2010;8:1157-64.

6. Figueira RNM, Santos AI, Camargo ME, et al. Fatores que influenciam o padrão radiológico de densidade das mamas. Radiol Bras. 2003;36: 287-91.

7. Yaghjyan L, Mahoney MC, Succop P, et al. Relationship between breast cancer risk factors and mammographic breast density in the Fernald
Community Cohort. Br J Cancer. 2012;106:9961003.

8. Couto E, Qureshi SA, Hofvind S, et al. Hormone therapy use and mammographic density in postmenopausal Norwegian women. Breast Cancer Res Treat. 2012;132:297-305.

9. Chen FP, Cheung YC, Soong YK. Factors that influence changes in mammographic density with postmenopausal hormone therapy. Taiwan J Obstet Gynecol. 2010;49:413-8.

10. American College of Radiology. Breast Imaging Reporting and Data System ${ }^{\circledR}$ (BI-RADS®) Atlas. 4th ed. Reston, VA: American College of Radiology; 2003.

11. Godinho ER, Koch HA. Breast Imaging Reporting and Data System (BI-RADS ${ }^{\mathrm{TM}}$ ): como tem sido utilizado? Radiol Bras. 2004;37:413-7.

12. Balleyguier C, Ayadi S, Van Nguyen K, et al. BIRADS classification in mammography. Eur J Radiol. 2007;61:192-4.

13. Berg WA. Supplemental screening sonography in dense breasts. Radiol Clin North Am. 2004;42: 845-51.

14. Boyd NF, Guo H, Martin LJ, et al. Mammographic density and the risk and detection of breast cancer. N Engl J Med. 2007;356:227-36.

15. Kolb TM, Lichy J, Newhouse JH. Comparison of the performance of screening mammography, physical examination, and breast US and evaluation of factors that influence them: an analysis of 27,825 patient evaluations. Radiology. 2002; 225:165-75.

16. Houssami N, Irwig L, Simpson JM, et al. Sydney Breast Imaging Accuracy Study: comparative sensitivity and specificity of mammography and sonography in young women with symptoms. AJR Am J Roentgenol. 2003;180:935-40.

17. Lokate M, Kallenberg MG, Karssemeijer N, et al. Volumetric breast density from full-field digital mammograms and its association with breast cancer risk factors: a comparison with a threshold method. Cancer Epidemiol Biomarkers Prev. 2010;19:3096-105.

18. Berg WA, Gutierrez L, NessAiver MS, et al. Diagnostic accuracy of mammography, clinical examination, US, and MR imaging in preoperative assessment of breast cancer. Radiology. 2004; 233:830-49.

19. Harvey JA, Bovbjerg VE. Quantitative assessment of mammographic breast density: relationship with breast cancer risk. Radiology. 2004; 230:29-41.

20. Corsetti V, Ferrari A, Ghirardi M, et al. Role of ultrasonography in detecting mammographically occult breast carcinoma in women with dense breasts. Radiol Med. 2006;111:440-8.

21. Jiang Y, Miglioretti DL, Metz CE, et al. Breast cancer detection rate: designing imaging trials to demonstrate improvements. Radiology. 2007; 243:360-7.

22. Berg WA, Blume JD, Cormack JB, et al. Combined screening with ultrasound and mammography vs mammography alone in women at elevated risk of breast cancer. JAMA. 2008;299: 2151-63.

23. Youk JH, Kim EK. Supplementary screening sonography in mammographically dense breast: pros and cons. Korean J Radiol. 2010;11:589-93.

24. Siqueira RFCB, Sá DSB, Pinto Neto AM, et al. 
Fatores associados à densidade mamográfica de mulheres na pós-menopausa. Rev Bras Ginecol Obstet. 2004;26:45-52.

25. Fonseca-Alaniz MH, Takada J, Alonso-Vale MIC, et al. The adipose tissue as a regulatory center of the metabolism. Arq Bras Endocrinol Metab. 2006;50:216-29.

26. Sung J, Song YM, Stone J, et al. High-density lipoprotein cholesterol, obesity, and mammographic density in Korean women: the Healthy Twin study. J Epidemiol. 2011;21:52-60.

27. Kelemen LE, Pankratz VS, Sellers TA, et al. Age- specific trends ind mammographic density: the Minnesota Breast Cancer Family Study. Am J Epidemiol. 2008;167:1027-36.

28. Mezzacapa MAMS, Mezzacapa Filho FM. Lactação: fisiologia e assistência. In: Neme B, editor. Neme - Obstetrícia básica. $3^{\mathrm{a}}$ ed. São Paulo, SP: Sarvier; 2005. p. 215-20.

29. El-Bastawissi AY, White E, Mandelson MT, et al Reproductive and hormonal factors associated with mammographic breast density by age (United States). Cancer Causes Control. 2000;11: 955-63.
30. Yaghjyan L, Mahoney MC, Succop P, et al. Relationship between breast cancer risk factors and mammographic breast density in the Fernald Community Cohort. Br J Cancer. 2012;106:9961003.

31. Nothacker M, Duda V, Hahn M, et al. Early detection of breast cancer: benefits and risks of supplemental breast ultrasound in asymptomatic women with mammographically dense breast tissue. A systematic review. BMC Cancer. 2009; $20 \cdot 335$. 